\title{
Bioethics applied in a public health research
}

\author{
Bioética en la realización de una investigación en salud pública
}

Rosa N. Villegas-Delgadillo ${ }^{a}$, Lydia López-Pontigo ${ }^{b}$

\begin{abstract}
:
This article highlights the importance of bioethics when a research in the field of public health is being carried out. Research in health care allows us to obtain advances such as: preventing diseases, diagnose them and treat them. The Pan American Health Organization (PAHO) states that Bioethics is the discipline that looks to explain ethical problems that emerge in relation to health by doing research on human beings, designing and implementing a health policy, and providing medical attention. Bioethics is not a code of precepts but an activity of analysis based on ethical principles and criteria that guide the medical praxis in several health care areas. In 2004, the UNESCO launched a program of ethical teaching which varies depending on the region and country, and demands special attention regarding moral issues that are relevant in such specific regions. Based on those recommendations and reports, the UNESCO launched that same year, the Program of Bioethics Teaching.
\end{abstract}

Keywords:

Bioethics, Research, Public Health

Resumen:

El presente artículo destaca la importancia que tiene la bioética cuando se realiza investigación en el área de Salud Pública. La investigación en salud es una vía que nos permite lograr avances tales como; prevenir enfermedades, diagnosticarlas y tratarlas. La Organización Panamericana de la Salud (OPS) señala que la Bioética es la disciplina que busca aclarar problemas éticos que surgen en relación a la salud: al hacer investigación con seres humanos, diseñar o implementar una política de salud, y brindar atención médica. La bioética no es un código de preceptos sino una actividad de análisis a la luz de principios y criterios éticos, que guía la práctica en las distintas áreas de la salud. Desde el 2004, la UNESCO lanzó el programa de enseñanza en ética, la cual varía considerablemente entre las regiones y los países, y exige una atención particular respecto a las cuestiones morales relevantes de estas regiones específicas. Sobre la base de dichas recomendaciones e informes, la UNESCO lanzó en 2004 el Programa de Enseñanza en Bioética.

\section{Palabras Clave:}

Boética, Investigación, Salud Pública

\section{INTRODUCTION}

To define the term of bioethics, the etymological bases of the word should be mentioned. Ethics comes from the Greek ethos that means a place where one lives. Aristotle defined it as the way of being or the character; and bios that means life. Therefore, the Word bioethics can be defined as the life ethics. But defining the term is not enough to understand completely the bioethical events; it is necessary to subtly go deeper into the basis of ethics.

The PAHO states that bioethics is the discipline that aims at explaining ethical issues that emerge in relation to health: by researching with human beings, designing and implementing health care policies, and providing medical attention. Bioethics is not a code of precepts, but an activity of analysis based on ethical principles and criteria which guide the medical praxis. The principles of Hippocratic ethics, mainly based on

\footnotetext{
${ }^{a}$ Corresponding author, Universidad Autónoma del Estado de Hidalgo, Instituto de Ciencias de la Salud, Email: rogue1515@hotmail.com

b Universidad Autónoma del Estado de Hidalgo, Instituto de Ciencias de la Salud, https://orcid.org/0000-0001-6901-7909, Email: lydial@uaeh.edu.mx
} 
recognizing a human in all its dimensions (material and spiritual), allowed a holistic approach of the health-disease process. But, since the 15 th century, with Renaissance, a revolution of human thinking, this approach changed. Medicine, already a scientific knowledge, developed its biomedical paradigm even with more strength (Sánchez, 2001). Through history, the term bioethics with a sense of ecology and population, was quickly applied to public health problems and biomedical researches, in such a way that it included the field of medical education and was expanded to its social projection (Navarro, 1999). Bioethics, associated to the scientific activity with human life turned crucial because of the tragic events occurred during the Second World War. Due to the abuses committed against the Jewish people, physicians and soldiers were judged and condemned in the Nuremberg Trials, leading to the creation of the Nuremberg Code. In 1964, the World Medical Association called to the Declaration of Helsinki; code that establishes a series of recommendation for the clinical researches. This is the most important guiding document regarding ethics on human being's experimentation (Brevis, 2007).

On the other hand, public health must be understood as the meeting point where biological, social, and behavioral sciences converge. It addresses the social and institutional answers to certain epidemiological conditions. Therefore, it is about a discipline that simultaneously articulates a medical model (health-disease concept), an institutional system of answers and a set of specific therapies that combines biological, political and social approaches. Its purpose is to promote health, prevent, diagnose and treat diseases and conditions, as well as promote physical and social rehabilitation (Juárez, 2002). Also, research is a way that allows us to accomplish advances like prevent, diagnose and treat diseases. Research in health goes together with ethics and represents a challenge for professionals who sometimes may not agree with methodological considerations, since the line between praxis and research is very narrow. That is why the students of Public Health must value research as a mean to knowledge construction, with the main objective of taking care of the population's health.

A researcher with no ethics puts his/her personal interests above the ethical values every professional is supposed to have. Science by itself generates ethical and social bonds like honesty and the need of cooperation and social exchange (Morales, 2011).

This way, it is necessary to review the importance of bioethics when a study group of university students is doing research, as well as knowing the General Health Law and the use of the informed consent.

In this sense, the decisions made in public health regarding health care, planning, clinical attention and biotechnology must be framed from a bioethical perspective taking into account conceptual elements that lead to several approaches: differential, life cycle, genre, ethnic and population, among others, always analyzed from a human rights (HRC) and social justice perspective in health; aspect that suggests to understand, reflect and decide on human rights (PDSP, 2012).

\section{Public health}

The essence of public health is to go beyond the individual. There are several meanings of public health, but all of them refer to the environment around the individual and take into account his/her family, community, and general society. Within this common vision, two poles can be identified: minimalist and maximalist (Darras, 2004). Either way, public health transforms the individual body into a socialized and normalized body. It goes from treating the disease to planning health (Hours, 2001). As a consequence, public health introduces a tension between the four basic principles of ethics (Coughlin, 1997).

It is necessary to include in this understanding some aspects like diversity, difference, multiculturality, socioeconomic and political conditions of health care, in a context of constant evolution of science and technology in our society, which also combine the awareness and moral action that are characteristic in a society going through a crisis of neo-conservatism and ethical relativism that affect an hermeneutical of bioethical phenomenology (Mendieta, 2016).

When it comes to teaching bioethics, it is necessary to generate in the students a positive attitude of reflection, alert and awareness about the ethical dilemmas that will probably come across their professional lives.

A strictly scientific education, updated and of a high academic level is not enough. It is necessary that in their learning process they not only get knowledge, but also skills and abilities to not only "know how to do it" but also prove the "reason to do it", and at the same time enhancing attitudes and ethical-moral values, that is, understanding the human qualities which offer us the opportunity to preserve life, appreciate our ancient culture, ennoble our existence, serve and not harm others, be honest, generous and tolerant. Ethical, social and human components should be an important part of students, teachers and the entire institution (Tellez, 2011).

\section{BIOETHICS}

Bioethics is not only applied ethics, it is the ethical reflection about principles given in a special field of knowledge, about basis, theories and moral principles. Also, it is not clinical ethics, consisting applying scientific and hospital knowledge to the cases. Yet, bioethics must be understood as a discipline that has gained great importance nowadays, where science gets together with a great technological advance, but it sometimes deprives the patient from human warmth and from their own right to life, as well as death (Suárez, 2002). Bioethics is taught because it is the discipline that covers the biological sciences to improve the life quality of humans, in the sense that it allows them to participate in their evolution. Physicians know they are technically capable of doing their job but they do not know if they must do it or not (Brevis, 2007). The four 
principles of medical bioethics (non-maleficence, beneficence, autonomy and justice) were understood since the beginning as universal principles to be linked with applied ethics (Do Céu Patrão,1996). It is important to develop research related with the ethics of care, behavior, and responsibility or researchers, the application of ethical principles and moral values of public health praxis in different scenarios. It is necessary to take into account that even when research is social, the ethical demands are the same in all the stages of the research process.

\section{Public heAlTh AND BIOETHICS}

Rising literature about bioethics of public health has generated debates beyond problems focused on the relation physicianpatient; therefore, in the bioethics of public health, there are unresolved researches, studies and approaches of social causes of population health, the structural corruption of state politics regarding the management of resources for public health, the disconnection of the former and the training of the health care professional (still framed in a curative model), trade and stratification of health (one for the rich, and other for the poor), among other aspects. In public health, bioethics has been contextualized from the guidelines of the World Health Organization (WHO) with the initiative Ethics and Health (2002), which guides the public policies of the health care sector. The aspects mentioned serve as a basis to reflect on the social importance of policies and the actual implications of the action, through conceptual foundations of the actual knowledge of public health and its relation with bioethics.

\section{GENERAL HEALTH LAW}

The main purpose of the right to a health protection is that all inhabitants enjoy basic health benefits of the same quality, efficacy and timing. Our Constitution is not the exception in defining health protection as a right (Elizondo, 2007). In terms of research in Mexico, the control is carried out through the General Health Lay Regulations in Terms of Health Research; the Regulations of the Federal Commission for the Protection against Sanitary Risk; the Official Mexican Standards, Agreements and Guidelines on the subject published in the Official Journal of the Federation, where the guidelines, procedures and principles that the research must follow, have been established (López, 2016). The compliance of these guidelines guarantees the protection of dignity, human rights, safety and welfare of the participants in the study. The General Health Law, chapter five "Research for Health", only section, establish the guidelines and principles that a research in the field of health care must follow involving human beings of biological samples from them.

\section{FREE AND INFORMED CONSENT}

The informed consent is the tangible expression of respect to the autonomy of people in the health care and health research fields. The informed consent is not a document, it is a continuous and gradual process between the health care personnel and the patient, which is established in a document (CONBIOETICA).

The informed consent has two parts:

a. Disclosure of information: the information given to the patient must be clear, true, sufficient, convenient, and objective regarding the attention process, mainly the diagnose, treatment, and prognosis of the condition. In the same way, it is important to inform about the risks, physical and emotional benefits, the duration and the alternatives, if there were any.

The process includes proving if the patient has understood the information, encouraging them to ask questions, providing them answers and counselling them if requested.

The data must be given to competent people in terms of the law, their age, and their mental capacity. In the case of people with limitations in conscience, reasoning or intelligence, it is necessary to get authorization from their legal representatives. However, whenever possible, it is better to have the patient's consent.

b. Voluntary nature of the decision: after being properly informed, the patient has the possibility to grant or not his/her consent so any procedure is carried out. It is important to favor the autonomy and establish the necessary conditions to exercise the right to decide.

Presented as respect to human dignity and to the autonomy of the participants, all the ethical requirements for the consent process are stated, highlighting the following: The protection of vulnerable subjects with a limited capacity or freedom. The consent in epidemiological research where there is contact of the individuals involved, is needed. The article 100 of the General Health Law establishes that the research in human beings must be adapted to scientific and ethical principles that justify the medical research; that it is the only method to obtain this knowledge; that the subject under experimentation is safe and not exposed to risks or unnecessary harm; that there is a written informed consent of the subject under research or his/her legal representative; and that only health professionals carry out the process.

\section{ETHICAR CODES}

A code is a set of rules encoded and ordered by chapters related to a specific topic and accepted by a community of individuals specialized and interested in the matter. In the next list there are the most important ethical codes in history (Fig. 1): 


\begin{tabular}{l}
\hline CÓDIGOS DE ÉTICA \\
\hline 1. Consejos de Esculapio \\
2. Oración de Maimónides \\
3. Juramento Hipocrático \\
4. Código Internacional de Ética Médica \\
5. Código de Nüremberg \\
6. Declaración de Budapest \\
7. Declaración de Helsinki \\
8. Declaración de Ginebra \\
9. Declaración de los Derechos Humanos \\
10. Declaración Universal sobre el Genoma y Derechos Humanos \\
\hline
\end{tabular}

Figure 1. Codes of Ethics

It must not be forgotten that simultaneously, the professional exercise is ruled by laws, which guide the activities that professionals do in terms of legal obligations. Therefore, there are exclusive rules that specific professionals must follow, like for example physicians, nurses, dentists, psychologists, pharmacists, physiotherapists, social workers, and clinical and paraclinical lab technicians, among others (Durante, 2011).

\section{RESEARCH HUMAN BEINGS}

In sum, bioethics deals with (according to the fundamental concepts of the general theory of systems) the full study of the conditions that must be taken into account for a harmonious development of individuals and the collectivity. Bioethics tackles ethical conflicts that emerge in the biological sciences as it can be the case of research in animals or the manipulation of their genetic structure, or problems derived from the use of petroleum-based fuels. So, medical ethics focus on the theoretical aspects of the medical sciences, as well as its practice.

To take into account the ethics in the development of a research, the application of autonomy, beneficence and justice should be identified and valued in each stage of the protocol and process of the research, under the responsibility of a Committee of Ethics in Research (General Health Law). To carry out any study, no matter the phase of the research you are at, whether it is to apply health resources, procedures or experimental activities in humans or biological samples from them, scientific, ethical, and regulatory principles (nationally and internationally accepted) must be respected. As it has been mentioned, the researcher must follow, at all times, the scientific and ethical principles that are nationally and internationally accepted to conduct clinical studies in Mexico (Fig. 2), even in the publication of reports, the confidentiality of the subjects under research must be preserved, as well as of that of the sponsors of the study. Besides, you must give credit to the associated researchers and the technical personnel who participate, and send a copy of the publications to the institution's address.

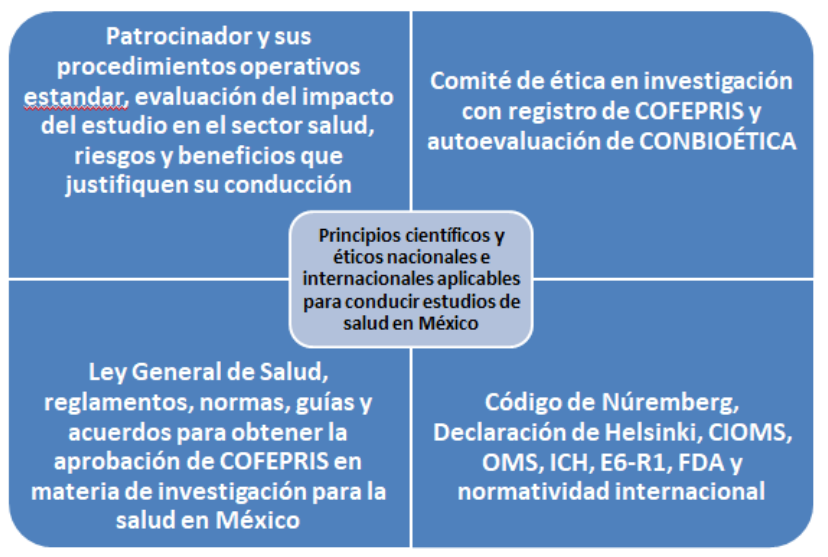

Figure 2. Scientific and ethical principles applied at a national and international level to conduct health studies in Mexico

\section{FINAL CONSIDERATIONS}

The consulted references to carry out this work provide an overview of the considerations that must be reviewed when someone wants to know the ethical aspects of health research. Bioethics includes all the health sciences and similar disciplines, it intervenes in biomedical research and human behavior, it covers a wide range of social aspects like those about public health, occupational health, international health, ethics of population growth and environmental control, among others. In the field of public health, the social and political repercussions of applying the results of the epidemiological studies lead to a specific bioethical load. The technical and scientific advance of epidemiology demands and update of its relation with ethical principles, therefore, it is important that the professionals in the field are informed and updated regarding their practice within research. As it was mentioned before, the bioethical aspects must be present and taken into account in every methodology, because the vulnerability of individuals will always be a priority, this means that an ethical evaluation must be performed to prevent the participants or groups from suffering physical or economical damage, or a loss of prestige or self-esteem after participating in a study. The possible risks must be informed and it must be proved that there are more benefits than risks. If delicate information is obtained, one must be discrete in communicating and explaining the results or conclusions. Researchers must respect the ethical rules stated in several regulations. On the other hand, researchers must have compatible interests with their partners, sponsors and participants in the study. It should be mentioned that it is the duty of researchers to submit their projects to the committees of ethical revision of their corresponding education or research centers to tackle any ethical dilemma, ethical complaint, and in general, topics related to ethics including rules and procedures, allowing to strengthen a culture based in ethical values and principles. 


\section{SUGGESTIONS}

By conducting a research protocol during the master's in Public Health at the Universidad Autónoma del Estado de Hidalgo, whose population of study are students of undergraduate degree; the approval from the Committee of Research Ethics was obtained. It is important to continue this certification process not only in this one, but in every research carried out in the Institution whose object of study are human beings.

To continue promoting values, but most importantly, value the Committees on Bioethics of the University as they deserve. To promote among the students and the faculty tools like the Lecture on Bioethics "Dr. Guillermo Soberón Acevedo" of the School of Health Sciences (ICSa), which allow to generate high quality research.

The scientific practice must follow consolidated guidelines which determine the ethical conduct of every professional who must always embrace them in their scientific labor

\section{REFERENCES}

Comisión Nacional de Bioética, (2007). Guía Nacional para la Integración y el Funcionamiento de los Comités de Hospitalarios de Bioética. Comisión Nacional de Bioética. Secretaria de Salud.

Couceiro, A. (2008). Enseñanza de la bioética y planes de estudios basados en competencias. EDUC MED.

Coughlin, S., Soskolone, C. y Goodman, K.(1997). Cases Studies in Public Health Ethics. Washington DC: American Public Health Association.

Darras, C. (2004). Bioética y Salud Pública: Al cruce de los caminos Acta bioethica, 10(2), 227-233. https://dx.doi.org/10.4067/S1726$569 \times 2004000200010$

Do Céu Patrão, M. (1996). Fundamentación antropológica de la bioética: expresión de un nuevo humanismo contemporáneo. Cuadernos del Programa Regional de Bioética.

Elizondo, C. (2007). El derecho a la protección de la salud. Salud Publica México.

González, A. y Díaz, S. Análisis de la Ley General de Salud. Salud Pública de México [serie en Internet]. [citada 27 Ene 2020]. Disponible en: http://saludpublica.mx/index.php/spm/article/view/503

Hardy, A. y Rovelo, J., (2015) Moral, ética y bioética. Un punto de vista práctico. Medicina e Investigación.

Hours, B. (2001). Pour une anthropologie de la santé. In: Systèmes et politiques de santé. Paris: Karthala.

Ivonne, B. (2007). La Bioética en la Enseñanza y la Investigación en Enfermería. Rev Cubana Enfermer.

Juárez S. (s/f). Ética y salud en el marco de la globalización [serie en Internet]. [citada 27 Ene 2020]. Disponible en: http://monografias.com/trabajos12/ensfin/ensfin.shtml\#LISTA

Lema, S., Toledo, S., Rosa, M., Rodríguez, A. y Almada, H. (2013) La ética de la investigación en seres humanos en debate. Rev Méd Urug.

López, M., Pimentel, C., Rivas, M., Mirelles, E. y Arredondo, J. (2016). Normatividad que rige la investigación clínica en seres humanos y requisitos que debe cumplir un centro de investigación para participar en un estudio clínico en México. Acta Pediatra México.

Martíbez, A., Laucirica, C., Llanes, A. La ética, la bioética y la investigación científica en salud, complementos de un único proceso.
Universidad de Ciencias Médicas de Matanzas, Cuba. 310-312 México [serie en Internet]. [citada 27 Ene 2020]. Disponible en: http://CUARTO/ARTÍCULO/ÉTICA\%20INVESTIGACIÓN\%20CIE NTÍFICA.pdf

Mendieta, S. (2016). Bioética de la Salud Pública. Universidad Militar Nueva Granada. Disponible: http://www.scielo.org.co/pdf/rlb/v17n2/1657-4702-rlb-17-0200001.pdf

Morales, G., Nava, C., Esquivel, S. y Díaz, P. (2017). Principios de ética, bioética y conocimiento del hombre. Universidad Autónoma del Estado de Hidalgo. Primera edición.

Navarro, V., Colás, M. y Alonso, M. (1999). Algunas reflexiones de la Bioética en las Ciencias Médicas. Educ Med Sup.

Organización Panamericana de la Salud (OPS). Programa Regional de Bioética. [serie en Internet]. [citada 27 Ene 2020]. Disponible en: https://www.paho.org/hq/index.php?option=com content \&view=articl e\&id=5582:regional-program-on-bioethics\&Itemid=4124\&lang=es

Reglamento de la Ley General de Salud en Materia de Investigación para la Salud. Diario Oficial de la Federación. Última reforma publicada 29-11-2019.

Rosa, O., Dominguez, A. y Malpica, C. (2008). Principios bioéticos aplicados a la investigación epidemiológica. Acta bioeth. [online]. 2008, vol.14, n.1 [citado 2020-01-27], pp.90-96. Disponible en: https://scielo.conicyt.cl/scielo.php?script=sci_arttext\&pid=S1726569X2008000100012\&lng=es\&nrm=iso>. ISSN 1726-569X.

Sánchez, L., Amaro, MC., Cruz, N. y Barriuso A. (2001). Introducción a la Medicina General Integral. La Habana: Editorial Ciencias Médicas.

Suárez, M., Téllez, E., Jasso, M. y Hernández, M. (2002). La Bioética y la Praxis de Enfermería. Instituto Nacional de Cardiología, Archivos de Cardiología de México. Vol. 72, suplemento 1, Enero-Marzo. México, D.F. 